\title{
CHINA'S TRADE POLICY TOWARDS CENTRAL AND EASTERN EUROPE IN THE 21ST CENTURY, EXAMPLE OF POLAND
}

Prof. Bogusława Drelich-Skulska

Sebastian Bobowski, Ph.D.

Anna H. Jankowiak, Ph.D.

Przemysław Skulski, Ph.D.

Wroclaw University of Economics

Faculty of Economic Sciences

International Economic Relations Department

Komandorska 118/120, Wroctaw, Poland

e-mail:kontakt@ue.wroc.pl

Received 12 December 2013, Accepted 8 July 2014

\begin{abstract}
The aim of this paper is to present China's economic model and discuss, in this context, bilateral trade and investment relations between China and Poland. The analysis presented herein is based on the strategy of cooperation with countries of Central and Eastern Europe, as presented by China's Prime Minister, and on the growing importance of Poland as a main partner of China in the Central and Eastern Europe region. The paper describes main premises of the Chinese economic model, followed by a diagnosis of Chinese economy. The authors analyze the main directions of China's foreign cooperation, placing the emphasis on relations with Poland.
\end{abstract}

Keywords: China's economic model, bilateral trade, investment relations, Central and Eastern Europe, Poland

JEL classification: F120, F130, F140. 


\section{Introduction}

China's accession to the World Trade Organization (WTO) in 2001 was a strong stimulus for economic development of the country and played an important role in the search for new directions of China's foreign economic policy. At the same time, the change of political and economic conditions on the global scale at the onset of the 21 st century, particularly the outburst of the global economic crisis of 2007/2008+, encouraged the Chinese central authorities to energize their diplomatic and economic relations with Central and Eastern European countries, also with Poland.

During his official visit in Warsaw in April 2012, at the Economic Forum "Poland-Eastern Europe-China", the then Prime Minister of Chinese Republic, Wen Jiabao, emphasized the growing importance of multidimensional cooperation and financial relations with 16 countries of Central and Eastern Europe (CEE), as a source of potential economic benefits for all parties involved.

The aim of this paper is to present China's economic model and discuss, in this context, bilateral trade and investment relations between China and Poland. The analysis presented herein is based on the strategy of cooperation with countries of Central and Eastern Europe, as presented by China's Prime Minister Wen Jiabao, and on the growing importance of Poland as a main partner of China in the CEE region. In addition, the paper presents an attempt at forecasting future directions of cooperation between both economies, in relation to the present economic policy trends observed in China. The first section of the paper describes main premises of the Chinese economic model, followed by a diagnosis of Chinese economy. The authors analyse the main directions of China's foreign cooperation, placing the emphasis on relations with Poland. Bilateral trade relations are discussed, together with analysis of import and export streams, commodity composition of trade and bilateral relations in the sphere of foreign direct investment.

\section{China's economic model}

China's economic model is characterized by high growth dynamics. There are, however, certain challenges to be met to maintain this fast tempo of economic growth, such as the need to balance growth trajectories across the region, growing disproportion of individual income, strong labour migration trends, low safety standards of Chinese products and, lastly, strong dependence of China's economy on export and investment ${ }^{1}$. 
One of the main characteristics of China's economic model is the continued trade surplus, subject in recent years to strong fluctuations due to internal political factors and external demand oscillation. From 1978 (the date of China's opening of the foreign trade) till 1990s, China's dynamics of economic growth was fuelled mainly by internal demand, strongly stimulated by governmental and household expenditures ${ }^{2}$. In the second half on the 190s decade, China's economic model has been largely redesigned by central authorities to make better use of external demand and fixed capital investment.

Setting aside the neo-classical concept of demand and its role in long-term economic development, based among others on the full use of resources, it must be assumed that the main source of China's growth dynamics is the aggregated demand, consisting of the following:

- Consumer demand, stimulated by increase of household income due to positive changes in income redistribution policy and institutional/political reforms;

- Private investment, stimulated by high potential return, and the resulting increase in demand and productivity;

- Public investment and government purchases;

- External demand as a potential source of foreign currencies as well as a factor influencing the structure of current account and, indirectly, other components of aggregated demand.

Thus defined, the aggregated demand includes the following elements: individual consumption, gross investment, government purchases, and export and import of goods and services.

In the years 1978-2007, China's economic model was subject to significant evolution, as reflected in the volume of aggregated demand components (Table 1).

Table 1. Components of China's aggregated demand and China's GDP growth in the years $1978-2007(\%)^{*}$

\begin{tabular}{|c|c|c|c|c|c|c|}
\hline Years & C & G & I & Ex & Im & $\begin{array}{c}\text { Aggregated GDP } \\
\text { growth }\end{array}$ \\
\hline $1978-1988$ & 52.29 & 12.5 & 31.03 & 17.4 & -19.62 & 10.1 \\
\hline $1988-1991$ & 27.49 & 26.44 & 6.48 & 51.6 & -25.87 & 5.7 \\
\hline $1991-2001$ & 43.75 & 17.0 & 39.28 & 25.22 & -24.75 & 10.3 \\
\hline $2001-2007$ & 24.17 & 10.0 & 46.54 & 57.44 & -42.75 & 10.7 \\
\hline
\end{tabular}

C - individual consumption, G - government purchases, I - gross investment, Ex - export of goods and services, Im - import of goods and services.

* - the authors disregarded data sets for 2008-2012, due to their incomparability in the period of economic crisis.

Source: The National Bureau... (2008), Tables 2-4, 2-17, 2-18; The National Bureau... (2009), pp. 22, 33-34; World Bank database (http://data.worldbank.org/indicator/NY.GDP.MKTP.KD.ZG?page=2); UNCTAD database (http://unctad.org/en/Pages/Statistics.aspx). 
The years 1978-1988 mark the period of sustained growth, stimulated by internal demand. It should be noted that household consumption's share in the dynamics of economic growth was over 52\%, with investment in fixed assets representing 31\%. The dynamic increase of household income was mainly associated with the increase of prices on agricultural products purchased centrally with the aim of stimulating the purchasing power in rural regions. The share of export in GDP growth was relatively low (17.4\%).

The years 1988-1991 represent a period of investment slowdown, with resulting drop of annual average growth in relation to the previous period $(5.7 \%$ from $10.1 \%)$. The drama of Tiananmen Square Incident and the growing inflationary pressures caused central authorities to adopt cooling measures through public investment cuts. The negative effects were countered by increased government purchases and devaluation of yuan, resulting in a marked increase of export share $(51.6 \%)$.

The period of 1991-2001 is a period of increased investment, marked by fast growth of gross investment and household consumption share in GDP (39.28\% and 43.75\%, respectively). The dynamic growth was also stimulated by political changes, namely the emphasis on market mechanisms and the share of private sector in China's economy. The inflationary pressures in the period of 1993-1994 were countered by cooling measures, such as further cuts of public investment and increased interest rates. Export was stimulated by gradual devaluation of yuan against US dollar and by tax deductions offered to businesses, but the recurring inflationary risk largely limited the effectiveness of these measures.

The last of the periods under study, directly preceding the period of global economic crisis, i.e. the years 2001-2007, was a period of economic growth, stimulated both by investment and export. In this period, China's economic growth dynamics resulted mainly from external demand (57.44\%) and fixed asset investments (46.54\%). The lower share of private consumption in GDP was a result of growing disproportion in individual income and the level of household savings, caused by dynamic privatization of national property and the rise of unemployment ${ }^{3}$. Consequently, the decidedly highest dynamics of economic growth in China since the introduction of new economic policy (reaching 13\% in 2007) was, in relative terms, the least determined by the increase in private consumption. However, the role of goods export and public infrastructural investment in the period under study was markedly higher after China's accession to the WTO structures. The above phenomena were accompanied by commercialization in the sectors of public health, education and real estate market resulting in increased household savings instead of stimulated individual consumption. 
To sum up, China's economic model shifted towards liberalization and free market over the three decades, as manifested by gradual reduction of individual consumption in the GDP growth, to the benefit of export and investment ${ }^{4}$. Presently, in times of global economic crisis, the role of investment increases, but the export's share is in decline, due to economic slowdown observed among the largest trade partners. The cooling of economy, particularly of the real estate market, designed to alleviate the inflationary pressures, implies the need for further stimulation of internal demand, as one of the most important components of aggregated demand and GDP growth dynamics in China under present economic conditions.

\section{Diagnosis of economic situation and perspectives for economic growth in China}

The People's Republic of China (PRC) is a prominent example of a country subject to consistent process of gradual market economy transformation. The fundaments of this process can be traced back to the Three Year Plan of economic development, passed by Chinese authorities n December 1978. The Three Year Plan is commonly perceived as the first clear impulse for comprehensive economic reforms in the country ${ }^{5}$. It is those reforms, gradually introduced in the decades to follow, that set in motion the economic transformation process and made China the fastest-growing major economy in the world.

In the light of the World Bank estimates, the growth rate of Chinese economy in 2012 was $8.2 \%$ (the lowest rate since 1999), with predicted rate of ca. $8.6 \%$ in $2013^{6}$. As a result of the global crisis of 2007/2008+, an average annual growth rate in China has dropped from 2 digit figures down to slightly over 9\% in the years 2009-2011, an impressive feat considering the present level of international economic uncertainty. McKinsey \& Company forecast the annual growth rate of Chinese economy up to 2020 at the level of $7.9 \%$, compared with $2.8 \%$ in the United States, $1.7 \%$ in Germany, 2\% in France and 1.2\% in Japan ${ }^{7}$. Moreover, the share of individual consumption in GDP growth in China will reach $43 \%$, coupled with relative drop of investment $(38 \%)^{8}$.

Since the beginning of the 21st century, social prosperity in China has grown at a steady pace, as measured by the per capita GDP. In the years 2000-2011, its value increased from 949 USD to 5,445 USD, i.e. more than fivefold. By 2020, this index is expected to grow up to the level of 9 thousand USD, compared to 57 thousand USD per capita over the same period in the United States. In comparison with G39 economies, particularly that of the eurozone, the United States and Japan, the 'Central Kingdom' displays impressive vitality, a power horse of global economy. 
Undoubtedly, the threefold growth of nominal GDP over the last decade cannot solve the present problem of significant economic slowdown. The slump in Chinese economy is a product of the authorities' strategy of cooling the economy and reducing inflation, which soared steadily since the 4 th quarter of 2010 , reaching $6 \%$ in the year 2011 . However, the forecasts predict stabilization of inflation rate at less than 3\% in the period of 2012-2014. In short-term perspective, the elevated inflation resulted in a dynamic increase of prices for imported goods by nearly $6 \%$ year on year in 2011 , with simultaneous increase of food prices at nearly $15 \%$ in the same period, due to poor harvest and increase of crop prices. However, by the end of 2011, the prices of food products and raw materials have stabilized, and inflation started to drop.

\section{China by the year 2025}

A fivefold increase of China's GDP by 2025

1 billion people will live in Chinese urban areas by 2030

350 million people will move to urban areas (i.e. more than the population of today's United States) 221 Chinese cities will reach 1 million-plus population (compared with 35 cities of this size in Europe at present)

5 billion square meters of roads will be paved

40 billion square meters of floor space will be built in 5 million of new buildings

50 thousand of the above constructions will be skyscrapers

Source: McKinsey Global Institute (2009, March), preparing for China's Urban Billion.

\subsection{Tightening of the economic policy}

In response to the inflationary pressure, Chinese monetary policy has been tightened, as attested by the rise of interest rates and reserve requirements for commercial banks. Liquidity restrictions have been reflected in the increase of loaning costs for banks. Increase of local government investment activities in 2009 has led to a rise of non-performing loans, forcing the banking supervision authorities to significantly limit the loan support for local infrastructural investment projects, demand the return of parts of the capital and intensify the monitoring regime of credit portfolios ${ }^{10}$.

At the end of 2011, in response to stabilized inflation level and decrease of bank loans, coupled with moderate rate of economic growth and decreased prosperity of developed economies, China decided to loosen its monetary policy. The reserve requirement ratio (RRR) was reduced by 50 basis points in December 2011, with further RRR reduction in February 
2012, resulting in a significant decrease of banks' operational costs and lessening of the pressure on financial markets. At the same time, however, the high interest rates were left unchanged.

Chinese authorities have also intervened on the real estate market, aiming to contain the rapid increase of property prices, particularly in metropolitan areas. Some large cities introduced additional restrictions in property investment, such as the extraordinary property taxes in Shanghai and Chongqing.

Fiscal policy has stimulated the economy. Tax revenues increased after 2010, almost to the point of balancing central and local budgets. At the same time, the social security system separated from central budget and managed by local authorities, saw a surplus of nearly $0.5 \%$ GDP, despite relative slowdown in real economy. By the end of 2011, public debt dropped to the level of $15 \%$ GDP, with only a marginal net debt of central government.

It must be noted that public debt should be adjusted to reflect the debt of Ministry of Railroads, Investment Fund Companies and local governments, increasing the actual public debt level to $35 \% \mathrm{PKB}^{11}$ as measured at the end of 2010 alone. However, the majority of investment projects - particularly in the wealthy regions of China - are considered secure or are covered by additional credit warranties.

\subsection{Balancing the economy}

Despite the restrictive character of fiscal and monetary policies, the internal demand increased in 2011. For the first time in the last decade, the share of total consumption in real GDP saw a marginal increase ${ }^{12}$. Retail sales increased by $12 \%$ in real figures, propelled by a marked increase of household income - reaching over $10 \%$ annually, particularly in rural areas. Employee income increased significantly, particularly for migrant workers from rural areas $^{13}$, who profited from the introduction of minimum wage rules in urban areas, most notably in the key export production provinces of Guangdong and Jiangsu.

Tightening of monetary policy brought a drop in dynamics of capital accumulation. Real estate market stagnated, developers limited their investment activities and sold off their reserves; there was a marginal drop of property prices, reduced in part by central government's social housing project. In 2011, the project involved construction of 10 million new flats, and further 7 million in 2012. The new housing projects are addressed to less affluent city dwellers.

The export, as measured in GDP share, dropped to the lowest level in 2009, reaching $27 \%$, with a marginal increase to ca. 30\% observed in the years 2010-2012. This slump was mainly associated with collapse on key export markets, such as the US market (due to rise of unemployment), the Euro zone (debt crisis) and the Japanese market (with economic slowdown 
caused by the earthquake, tsunami and power plant meltdown in March 2011). In addition, the inflationary pressure led to a marked decline in export dynamics, making it less competitive relative to other economies ${ }^{14}$.

In effect, the Chinese export sector was only marginally responsible for economic growth in 2011, with import dynamics slightly surpassing that of export dynamics. Consequently, terms of trade were affected, as manifested in the reduction of trade surplus to 2.2\% GDP and balance in current accounts to less than 3\% GDP in 2011. In addition, for the first time in more than a decade, 2011 has brought a decline of USD reserves, due to relative strengthening of the euro.

\subsection{Determinants of economic growth}

Central government's assumption that average annual growth rate of Chinese economy up to the year 2020 will oscillate around $7.9 \%$ is based on observation of economic situation of key export markets. Despite gradual increase of industrial production observed in 2012, forecasts of fluctuations in external demand are far from optimistic. Problems on global market, particularly in the Euro zone, with anticipated recession in Greece, Portugal and Spain, and marginal growth rate forecasts for Germany and France, will surely have a notable impact on Chinese economic growth rate in the years to follow.

In respect to internal markets, China has employed the practice of deliberate cooling off of the real estate market, which has direct influence on growth rate of construction sector and other key sectors directly involved in construction, such as cement and steel industries. The slump in real estate market is also reflected in demand, by reducing the local authorities' revenues from land turnover. In the light of decreased demand for land property rights on the part of developers, local authorities will rather withdraw from land auctions than allow the prices to drop, since the opening bids are often considered exorbitant. Since 2012, decreased revenues have led to a drop in infrastructure investment dynamics of the public sector and a marked increase of loan demand.

With the view of stimulating the economy, Chinese central government decided to raise the tax thresholds in September 2011, limiting the tax-paying population from 84 million down to 24 million, at the cost of $0.3 \%$ GDP. In January 2012, a 10\% increase of pensions and allowances, at the cost of $0.4 \%$ GDP. The above regulations are expected to bring a nearly $2 \%$ increase of individual consumption. Central government took up an obligation to increase, by 2015, the number of social security beneficiaries by ca. $40 \%$, from $250 \mathrm{~m}$ to $350 \mathrm{~m}$ people. This policy will most likely contribute to further increase of consumption, since households will benefit from reduced pressure to amass savings for individual health and pension schemes. The sector 
of construction, on the other hand, is expected to profit from the governmental program of social housing, with commercial banks obliged to support local governments with preferential loans. There are also plans to extend financial support for the program using dividends from stateowned companies.

Taking into consideration the strength of internal demand relative to other major economies of the world and marginal drop of competitiveness due to periodic increase of inflation, the surplus on current account should remain low. For example, in the years 2008-2011, current account surplus dropped by $50 \%$, i.e. from 420 bn USD to 202 bn USD in volume.

The short-term priority of Chinese central government is to return to the path of rapid growth. This will require skilful management of external uncertainty and imbalance at the level of macroeconomic policy. On internal market, the monetary policy should be loosened through a decrease of required reserves and interest rates, as means of stimulating internal demand in the years to follow. Changes are required also in respect to fiscal policy, as well as the policy of balancing the central budget and increase of current account surplus. In fact, taking into account the medium-term trajectory of dynamic economic growth and the low cost of public debt, central government can afford to maintain deficit at the level of $2 \%$ GDP, even at marginal increase of debt to GDP ratio.

Of key importance for Chinese economy is the situation on real estate market, since the balancing of prices is accompanied by steady fall in demand, with resulting increase of pressure on developers. Mounting losses pose a risk for the financial sector, particularly when they start to affect large companies in the sector. This, in turn, may translate to losses on the part of purchasers, due to steady fall of prices and potential bankruptcy of developers before the investment is completed - particularly in the light of advance payment schemes. Admittedly, the pace of urbanization and increase of individual income should restore the market equilibrium, but the huge excess supply and steady fall of demand do not offer potential for durable improvement in the sector. The largest commercial banks are financially balanced and report relatively low pool of non-performing loans ${ }^{15}$. However, in the face of potential non-performance of some infrastructural projects financed by those institutions, the situation may deteriorate. Central authorities have already announced their intent to introduce reforms in financial sector to minimize the systemic risk, particularly in relation to the mounting debt of local governments. Reforms are also planned in supervision.

Another important risk factor for China is the continued decline of external demand, due to prolonged economic stagnation of G3 markets. The euro zone still faces the problem of debt crisis and low trust in financial sector; fiscal policy of the US government is ineffective 
in terms of stimulating the economic growth, while Japan has to deal with mounting cost of long-term state debt caused by delayed fiscal consolidation in the aftermath of nuclear power plant crisis.

To sum up, departure from the investment model of growth in favour of consumptionstimulated growth will require considerable effort on the part of Chinese authorities. Internal market stimulation should focus on:

- keeping up the pace of urbanization,

- reforms of the social security system,

- reforms of financial sector and industrial policy,

- boosting employment in the services sector, particularly in retailing and finance,

- increasing the household income growth rate.

In effect, the Chinese economy dynamics will be even more dependent on rapid agglomeration of urban cluster structures ${ }^{16}$, such as Chengdu and Shangdong, each with economic potential comparable to that of medium-sized EU economies, such as Belgium or Austria.

Chinese foreign policy, in the face of continued economic slowdown of G3 countries, will focus on active pursuance of contracts with developing countries, including the CEE region. It must also be noted that this trend of multidimensional contacts with developing countries all over the world has been an important element of Chinese economic strategy for more than a decade now. This is manifested in the growing trade turnover with this group of countries. The largest share in goods export in the years 2000-2010 was associated with developing countries of the East Asia and Pacific region, followed by Central America and the Caribbean countries, with Europe and Central Asia placing third. At the same time, it should be noted that, in the period under study, the largest increase in Chinese goods export share was associated with developing countries of Europe and Central Asia, from 1.87\% in 2000 to $4.55 \%$ in 2010, with a record share of $5.73 \%$ in 2008. Similar trends can be observed in the same period in the structure of Chinese goods import from developing countries, but with strong dominance of East Asia and Pacific region with 9.61\% share in 2010. Central America and the Caribbean countries placed second, with 6.48\% share, followed by Sub-Saharan Africa - 3.99\%. Europe and Central Asia countries placed fourth in the structure of Chinese goods import in 2010, with $3.35 \%$ share (Table 2). 
Table 2. Chinese trade turnover with developing countries of selected world regions in the years 2000-2010 (in \% of export/import, overall)

\begin{tabular}{|l|c|c|c|c|c|}
\hline \multicolumn{1}{|c|}{ World region } & 2000 & 2004 & 2008 & 2009 & 2010 \\
\hline \multicolumn{7}{|c|}{ Goods export } \\
\hline East Asia \& Pacific & 4.89 & 5.27 & 5.96 & 6.64 & 6.96 \\
\hline Europe \& Central Asia & 1.87 & 3.13 & 5.73 & 4.33 & 4.55 \\
\hline Central America \& Caribbean & 2.83 & 2.99 & 4.90 & 4.63 & 5.69 \\
\hline Middle East \& North Africa & 1.29 & 1.49 & 2.09 & 2.54 & 2.38 \\
\hline South Asia & 1.52 & 1.89 & 3.10 & 3.48 & 3.64 \\
\hline Sub-Saharan Africa & 1.42 & 1.66 & 2.52 & 2.73 & 2.74 \\
\hline & Goods import & & \multicolumn{3}{c|}{} \\
\hline East Asia \& Pacific & 7.78 & 8.92 & 8.82 & 9.10 & 9.61 \\
\hline Europe \& Central Asia & 3.43 & 3.10 & 3.23 & 3.32 & 3.35 \\
\hline Central America \& Caribbean & 2.40 & 3.86 & 6.29 & 6.33 & 6.48 \\
\hline Middle East \& North Africa & 1.52 & 1.34 & 2.54 & 2.31 & 2.49 \\
\hline South Asia & 0.84 & 1.49 & 1.90 & 1.51 & 1.65 \\
\hline Sub-Saharan Africa & 2.25 & 2.41 & 4.35 & 3.67 & 3.99 \\
\hline
\end{tabular}

Source: own research based on World Bank statistical data.

Growing interest in trade relations with countries of Central and Eastern Europe can also be attested by the diplomatic offensive initiated by central Chinese authorities in this region in the first decade of the 21 st century.

\section{Directions of economic cooperation between China and countries of Central and Eastern Europe (CEE), Poland included}

People's Republic of China joined the World Trade Organization on November 112001 , at the Doha Ministerial Conference in Qatar, as the 143rd member. WTO membership involved subordination of Chinese foreign economic policy to the rules of the organization, with emphasis on liberalization of global trade in goods, services, capital and technologies.

China's accession to the WTO structures had a positive impact on the global trade position of China in the years 2001-2011. PRC became a global trade power, gaining comparative advantage in many industrial sectors. This advantage stems principally from nearly unlimited supply of workforce, with growing technical qualifications, in production companies localized mainly in industrial clusters in the eastern and southern regions of China. Effective interaction with foreign markets is further improved by continuous development of transport infrastructure and logistics services. 
The chief assets of Chinese economy, presented above, are strongly supported by the country's foreign economic policy, well-designed and well-implemented, with precisely defined directions of expansion, both by sector and by geographic location. Cooperation with CEE countries is one of the priorities of this policy, as attested by Prime Minister Wen Jiabao in his speech made on April 262012 in Warsaw at the Economic Forum "Poland - Central Europe China". The main directions of this policy were outlined in 12 points, presented below ${ }^{17}$ :

1. Setting up a China-Central and Eastern European Countries' Cooperation Secretariat, situated at the Chinese Ministry of Foreign Affairs. The Secretariat will be in charge of communication and coordination in all matters of economic cooperation, preparation of governmental meetings and business forums, as well as implementation of the tasks agreed upon during those meetings. The 16 countries of the CEE, on voluntary principle, will set up an institution and a co-ordinator as their representatives in the Secretariat's proceedings.

2. Chinese government will set up a special credit line of 10 billion USD, partly in the form of subsidized loans to facilitate the bilateral cooperation in IT industry, infrastructure construction and green economy. The 16 countries of CEE region may submit their project applications to National Development Bank of China, Export and Import Bank of China, Industrial and Commercial Bank of China, Construction Bank of China, Bank of China or China CITIC Bank.

3. A special fund for investment cooperation between China and CEE countries will be set up, with 500 billion USD directed to the fund in the first phase of the project.

4. China will send assignments to promote trade and investment in CEE region and will initiate active measures to form bilateral economic and trade cooperation. China intends to cooperate with CEE to boost the volume of bilateral trade to 100 billion USD by the year 2015.

5. In the light of practical needs of the CEE countries, China will actively promote cooperation with CEE among its local business, with the intent of setting up special economic zones in each of the CEE countries within the next five years or participating in the existing SEZ and technological parks in the region.

6. China is open to active pursuance of financial cooperation with CEE countries, in the form of: currency swaps, settling cross-border trade in local currencies, and setting up local branches of banks on principle of mutuality, to facilitate flexibility in bilateral cooperation. 
7. An advisory board will be set up to discuss the potential of establishing a direct transportation route between China and CEE. Chinese Ministry of Trade (as coordinator) and 16 countries of CEE region (voluntarily) will explore the possibility of support for local road networks or construction of a model railroad network in joint venture form or using other forms of cooperation.

8. China postulated setting up a forum of cultural cooperation with CEE countries in China in 2013, and to promote regular meetings of governmental and expert panels to propagate bilateral exchange on cultural level, in the form of arts and culture festivals and other cultural activities.

9. Chinese government declares their intention to grant 5 thousand scholarships to young students from CEE countries in the next 5 years, as well as their support for Confucius Institutes and a 'Confucius class' program in those countries. Within the next 5 years, Chinese government will invite 1 thousand students to study Chinese language in Chinese universities. Actions will be taken to support university exchange programs and bilateral research programs. One thousand Chinese students and researchers will be sent to CEE countries within the next 5 years. In 2013, Chinese Ministry of Education planned to host an international panel to discuss the issues involved in the international dialogue in education with CEE countries.

10. China postulates setting up an association to promote tourism in China and CEE countries, to be coordinated by China Tourism Administration. The postulated body will include representatives of civil aviation authorities, travel agencies and aviation companies from all parties involved. The postulated alliance will serve the purpose of promoting business relations and tourism, as well as examining the potential of increasing direct air links between China and the 16 countries of the CEE region. China Tourism Administration has already been involved in promotion of tourist products of both China and the CEE countries at the Chinese International Travel Fair in Shanghai in autumn 2012.

11. Setting up a research fund to promote studies of bilateral relations between China and the CEE. China declares its intention to direct 2 million $\mathrm{CNY}^{18}$ annually to support academic exchange between research institutes and scientists of both parties.

12. In 2013, China planned to host the first international forum of young political leaders from China and the CEE; representatives of young generation of political activists from both parties are to be invited, with the intention to promote understanding and friendship. 
It must also be noted that China perceives Central Europe as a separate and independent region, outside Russian and German spheres of influence. This trend should be emphasized and utilized in the course of building mutual relations with Beijing, taking into consideration the general Chinese preference for bilateral relations, rather than multilateral or community relations ${ }^{19}$.

\section{Trade relations between China and Poland in 21st century}

Legal fundaments of trade relations between China and Poland in 21st century are regulated by a number of bilateral agreements, but also by international agreements, most notably those contained in WTO provisions. This can be seen as a new and important institutional factor, defining the perspectives of economic cooperation between China and Poland, also in respect to trade, since the introduction of internationally recognized standards of trade forms a strong incentive for Polish exporters.

Trade relations between China and Poland at the onset of the 21st century are characterized by low dynamics of Polish export, high dynamics of import from China and fairly disadvantageous commodity pattern of trade (from Poland's standpoint). This is caused by a number of factors, both in terms of limited export offer of Poland, and barriers to trade with China.

Table 3. Foreign trade between China and Poland in the years 2000-2011

(export and import in goods, current market prices, in millions USD)

\begin{tabular}{|c|c|c|c|c|c|}
\hline \multirow{2}{*}{ Year } & \multicolumn{2}{|c|}{ Export } & \multicolumn{2}{c|}{ Import } & Balance \\
\cline { 2 - 6 } & in millions USD & \% of total export & in millions USD & \% of total import & in millions USD \\
\hline 2000 & 97.3 & 0.3 & $1,378.5$ & 2.8 & $-1,281.2$ \\
\hline 2002 & 206.8 & 0.5 & $2,077.5$ & 3.8 & $-1,870.7$ \\
\hline 2004 & 448.8 & 0.8 & $3,287.2$ & 4.6 & $-2,838.4$ \\
\hline 2006 & 606.9 & 0.7 & $6,169.1$ & 6.1 & $-5,562.2$ \\
\hline 2008 & 867.0 & 0.7 & $11,466.0$ & 8.0 & $-10,599.0$ \\
\hline 2010 & $1,229.0$ & 1.0 & $12,615.0$ & 9.4 & $-11,386.0$ \\
\hline 2011 & $1,347.0$ & 1.0 & $13,245.0$ & 8.7 & $-11,899.0$ \\
\hline
\end{tabular}

Source: Rocznik Statystyczny Handlu Zagranicznego (issues 2004-2012).

In 2004, i.e. in the year of Poland's accession to EU structures, trade turnover between China and Poland was 3,736.0 m USD, with export of $448.8 \mathrm{~m}$ USD (over $77.4 \%$ higher than the year before), and import volume of 3,287.2 m USD (an increase of 13.7\%, respectively). The current account deficit in 2004 was 2,838.4 m USD and - characteristically - was observed in all commodity groups. In 2011, total trade turnover with China reached 14,592 m USD, with export 
constituting 1,347 m USD (a threefold increase compared with 2004 figures), and import trade volume of 13,245 m USD (four times the volume compared with 2004 data). Hence, the current account deficit in 2011 reached an exorbitant volume of 11,899 m USD. In the first decade of the 21 st century, trade deficit with China increased more than nine times (Table 3), attesting to the lack of skills on the part of Polish exporters to utilize their export potential on Chinese market.

In the years 2004-2011, the structure of Polish export to China, relative to previous years, improved marginally due to the introduction of new export commodity groups (transport equipment, electrical appliances, furniture and vegetable products). However, the export structure remains fairly non-diversified - with three major SITC classification commodity groups constituting more than $84 \%$ (manufactured goods classified chiefly by material $-49.61 \%$, machinery and transport equipment $-21.2 \%$, and chemicals and related products $-13.65 \%)^{20}$. In 2011, the dominant commodity groups in Polish export to China were: non-ferrous metals (43.19\%, an increase from $22.45 \%$ in 2004$)$, organic chemicals $(10.58 \%$, a decrease from 19.98\%), electrical machinery, apparatus and appliances (7.86\%, an increase from $3.32 \%$ ) and furniture and parts thereof (4.29\%, an increase from a marginal volume of $0.67 \%$ in 2004).

The structure of Polish import from China in the last decade has been fairly stable (see Table 4 for SITC specification by section, Appendix 1 for SITC specification by division), with two dominant commodity groups by SITC classification: machinery and transport equipment (55.9\% in 2011, predominantly office machines and automatic data-processing machines, electrical machinery, apparatus and appliances, telecommunications apparatus and equipment) and manufactured goods classified by material (16.39\% in 2011, predominantly manufactures of metal, textile yarn, fabrics and made-up articles). Other Chinese import commodities popular on Polish market include clothes and clothing accessories (6.82\% in 2011) and assorted commodities, such as arms, toys and jewellery (6.69\% in 2011).

Table 4. Structure of Polish foreign trade with China in 2004 and 2011 (\%), by SITC commodity specification standards (by section)

\begin{tabular}{|l|c|c|c|c|}
\hline \multirow{2}{*}{ Specification by section } & \multicolumn{2}{c|}{ Import } & \multicolumn{2}{c|}{ Export } \\
\cline { 2 - 5 } & 2004 & 2011 & 2004 & 2011 \\
\hline \multicolumn{1}{|c|}{1} & 2 & 3 & 4 & 5 \\
\hline Food and live animals & 2.39 & 2.18 & 0.90 & 1.87 \\
\hline Beverages and tobacco & 0.02 & 0.20 & 0.02 & 0.01 \\
\hline Crude materials inedible, except fuels & 3.71 & 1.27 & 2.67 & 4.87 \\
\hline Mineral fuels, lubricants and related materials & 0.06 & 0.18 & 0.01 & 0.52 \\
\hline Animal and vegetable oils, fats and waxes & 0.00 & 0.01 & 0.00 & 0.00 \\
\hline Chemicals and related products & 4.12 & 4.45 & 21.68 & 13.65 \\
\hline Manufactured goods classified chiefly by material & 16.49 & 16.39 & 33.98 & 49.61 \\
\hline
\end{tabular}




\begin{tabular}{|l|r|r|r|r|}
\hline \multicolumn{1}{|c|}{1} & \multicolumn{1}{|c|}{4} & \multicolumn{1}{|c|}{5} \\
\hline Machinery and transport equipment & 42.50 & 52.36 & 37.85 & 21.20 \\
\hline Miscellaneous manufactured articles & 30.71 & 22.88 & 2.89 & 8.26 \\
\hline Commodities and transactions not classified elsewhere in SITC & 0.00 & 0.01 & 0.00 & 0.00 \\
\hline Total & 100.00 & 100.00 & 100.00 & 100.00 \\
\hline
\end{tabular}

Source: own research based on data from Eurostat, European Commission, http://epp.eurostat.ec.europa.eu.

Some of the more prospective areas of economic cooperation between Polish companies and Chinese partners include: mining industry (machinery, methanometers, safety equipment); marine industry (compression-ignition engines and components, high output diesel engines, shipbuilding technologies, navigation instruments and on-board IT systems, terminal tractors, recreation vessels, accessories and design); aviation industry (production of specialized airplanes in China, supply of spare parts and equipment, design and construction of airport infrastructure); medical equipment (diagnostic and clinical apparatus, implants and artificial organs, surgical and rehab appliances, medical software, spare parts and accessories); renewable energy (thin film photovoltaic technologies, efficient controllers and bearings, composites, submerged installations, marine electronics, generators, control systems and converters); green construction (sustainable design, HVAC systems, new construction and insulation materials [slag cement, extruded polystyrene EPS and XPS, double-glazed windows], water recycling and treatment systems) ${ }^{21}$; automotive parts (vehicle and motorcycle engines [particularly below $1.6 \mathrm{cc}$ ], anti-lock brake systems, automatic transmission systems, fuel cell technologies, attested tuning and modification parts); furniture industry, farm and food industry (powdered milk, meat, sweets, bakery goods, health food) and luxury goods (leather clothes and accessories, beauty and health products, perfumes, jewellery $)^{22}$.

Foreign direct investment is another area of further development in bilateral relations. Unfortunately, the present FDI volume does not reflect the potential and trends of both Chinese and Polish economy, despite the fact that Poland is regarded as the third most important FDI target for China in CEE region, next to Hungary and Romania.

At present, the CEE region is not a target of major foreign direct investment for China. Chinese investors display marked preference for countries of the Western Europe. In 2005, according to data published by the Ministry of Commerce of People's Republic of China, as much as $97 \%$ of the FDI flow was directed to EU-10 countries. Similar trend was observed in 2007 (97\%), and 2010 (93\%) (see Table 5). Of the EU-10 countries, the largest FDI flow was observed in Luxembourg, Sweden and Germany. In the group of new EU members, the largest China's FDI flows were directed to Hungary and Poland. 
Table 5. China's outward FDI flows into EU countries 2005-2010 (millions of USD)

\begin{tabular}{|l|c|c|c|c|c|c|}
\hline \multicolumn{1}{|c|}{ Country } & 2005 & 2006 & 2007 & 2008 & 2009 & 2010 \\
\hline EU-15 & 184.17 & 109.53 & $1,013.51$ & 428.53 & $2,928.94$ & $5,548.89$ \\
\hline Austria & - & 0.04 & 0.08 & - & - & 0.46 \\
\hline Belgium & - & 0.13 & 4.91 & - & 23.62 & 45.33 \\
\hline Denmark & 10.79 & -58.91 & 0.27 & 1.33 & 2.64 & 1.61 \\
\hline Finland & - & - & 0.01 & 2.66 & 1.11 & 18.04 \\
\hline France & 6.09 & 5.60 & 9.62 & 31.05 & 45.19 & 26.41 \\
\hline Germany & 128.74 & 76.72 & 238.66 & 183.41 & 179.21 & 412.35 \\
\hline Greece & - & - & 0.03 & 0.12 & - & - \\
\hline Ireland & - & 25.29 & 0.20 & 42.33 & -0.95 & 32.88 \\
\hline Italy & 7.46 & 7.63 & 8.10 & 5.00 & 46.05 & 13.27 \\
\hline Luxemburg & - & - & 4.19 & 42.13 & 2270.49 & 3207.19 \\
\hline Netherlands & 3.84 & 5.31 & 106.75 & 91.97 & 101.45 & 64.53 \\
\hline Portugal & - & - & 0.00 & - & - & - \\
\hline Spain & 1.47 & 7.30 & 6.09 & 1.16 & 59.86 & 29.26 \\
\hline Sweden & 1.00 & 5.30 & 68.06 & 10.66 & 8.10 & 1367.23 \\
\hline United Kingdom & 24.78 & 35.12 & 566.54 & 16.71 & 192.17 & 330.33 \\
\hline EU-10 since 2004 & 0.78 & 9.57 & 23.81 & 26.11 & 34.63 & 387.04 \\
\hline Cyprus & - & - & 0.30 & - & - & - \\
\hline Czech Rep. & - & 9.10 & 4.97 & 12.79 & 15.60 & 2.11 \\
\hline Estonian & - & - & 0.00 & - & - & - \\
\hline Hungary & 0.65 & 0.37 & 8.63 & 2.15 & 8.21 & 370.10 \\
\hline Latvia & - & - & -1.74 & - & -0.03 & - \\
\hline Lithuania & - & - & 0.00 & - & - & - \\
\hline Malta & - & 0.10 & -0.10 & 0.47 & 0.22 & -2.37 \\
\hline Poland & 0.13 & - & 11.75 & 10.70 & 10.37 & 16.74 \\
\hline Slovakia & - & - & 0.00 & - & 0.26 & 0.46 \\
\hline Slovenia & - & - & 0.00 & - & - & - \\
\hline EU-27 since 2007 & 4.59 & 9.63 & 6.80 & 11.98 & 2.86 & 27.13 \\
\hline Bulgaria & - & - & 0.00 & - & -2.43 & 16.29 \\
\hline Romania & 9.63 & 6.80 & 11.98 & 5.29 & 10.84 \\
\hline Total EU & 189.54 & 128.73 & $1,044.12$ & 466.62 & $2,966.43$ & $5,963.06$ \\
\hline & & & & & \\
\hline & - & & & & & \\
\hline
\end{tabular}

Source: own research based on PRC's Ministry of Commerce (2010), p. 100.

Analysis of aggregated value of China's foreign direct investment in Europe shows the dominant position of the EU-10, receiving 93\% of total FDI flow in 2010 (Table 6). It must be noted that the volume of China's FDI in Europe grows at a steady rate. In the years 2005-2010, total value of China's FDI in the region increased over 16 times, and more than doubled in the years 2009-2010. 
Table 6. China's outward FDI stock into EU countries 2005-2010 (millions of USD)

\begin{tabular}{|l|r|r|r|r|r|r|}
\hline \multicolumn{1}{|c|}{ Country } & \multicolumn{1}{c|}{2005} & \multicolumn{1}{c|}{2006} & \multicolumn{1}{c|}{2007} & \multicolumn{1}{c|}{2008} & \multicolumn{1}{c|}{2009} & \multicolumn{1}{c|}{2010} \\
\hline EU-15 & \multicolumn{1}{c}{$1,036.51$} & $2,652.25$ & $2,833.91$ & $5,882.41$ & $11,666.65$ \\
\hline Austria & 0.07 & 0.32 & 4.04 & 4.04 & 1.55 & 2.01 \\
\hline Belgium & 2.34 & 2.67 & 33.98 & 33.30 & 56.91 & 101.01 \\
\hline Denmark & 96.59 & 36.48 & 36.75 & 38.08 & 40.79 & 42.47 \\
\hline Finland & 0.90 & 0.93 & 0.94 & 3.59 & 9.04 & 27.25 \\
\hline France & 33.82 & 44.88 & 126.81 & 167.13 & 221.03 & 243.62 \\
\hline Germany & 268.35 & 472.03 & 845.41 & 845.50 & $1,082.24$ & $1,502.29$ \\
\hline Greece & 0.35 & 0.35 & 0.38 & 1.68 & 1.68 & 4.23 \\
\hline Ireland & 0.04 & 25.30 & 29.23 & 107.77 & 106.82 & 139.91 \\
\hline Italy & 21.60 & 74.41 & 127.13 & 133.60 & 191.68 & 223.80 \\
\hline Luxemburg & - & - & 67.02 & 122.83 & $2,484.38$ & $5,786.75$ \\
\hline Netherlands & 14.95 & 20.43 & 138.76 & 234.42 & 335.87 & 486.71 \\
\hline Portugal & - & 0.20 & 1.71 & 1.71 & 5.02 & 21.37 \\
\hline Spain & 130.12 & 136.72 & 142.85 & 145.01 & 205.23 & 247.76 \\
\hline Sweden & 22.46 & 20.02 & 146.93 & 157.59 & 111.89 & $1,479.12$ \\
\hline United Kingdom & 107.97 & 201.87 & 950.31 & 837.66 & $1,028.28$ & $1,358.35$ \\
\hline EU-10 since 2004 & 26.03 & 167.53 & 212.23 & 249.54 & 299.77 & 686.69 \\
\hline Cyprus & 1.06 & 1.06 & 1.36 & 1.36 & 1.36 & 1.36 \\
\hline Czech Rep. & 1.38 & 14.67 & 19.64 & 32.43 & 49.34 & 52.33 \\
\hline Estonia & 1.26 & 1.26 & 1.26 & 1.26 & 7.50 & 7.50 \\
\hline Hungary & 2.81 & 53.65 & 78.17 & 88.75 & 97.41 & 465.70 \\
\hline Latvia & 1.61 & 2.31 & 0.57 & 0.57 & 0.54 & 0.54 \\
\hline Lithuania & 3.93 & 3.93 & 3.93 & 3.93 & 3.93 & 3.93 \\
\hline Malta & 1.37 & 1.97 & 1.87 & 4.81 & 5.03 & 0.20 \\
\hline Poland & 12.39 & 87.18 & 98.93 & 109.93 & 120.30 & 140.31 \\
\hline Slovakia & 0.10 & 0.10 & 5.10 & 5.10 & 9.36 & 9.82 \\
\hline Slovenia & 0.12 & 1.40 & 1.40 & 1.40 & 5.00 & 5.00 \\
\hline EU-2 since 2007 & 42.42 & 70.37 & 77.62 & 90.40 & 95.65 & 143.55 \\
\hline Bulgaria & 4.99 & 4.74 & 4.74 & 4.74 & 2.31 & 18.60 \\
\hline Romania & 768.01 & $1,274.51$ & $2,942.10$ & $3,173.85$ & $6,277.83$ & $12,496.89$ \\
\hline Total EU & & & & & 17.95 \\
\hline So & & & & & & \\
\hline
\end{tabular}

Source: own research based on PRC's Ministry of Commerce (2010), p.101.

While Chinese businesses are not a major investor group for the new member states, the volume of Chinese investment in the CEE region grows steadily. This trend is particularly strong in the aforementioned countries: Hungary, Poland and Romania (Figure 1). In 2010, those three countries received a joint $88 \%$ of total China's FDI directed to the new EU member states. 


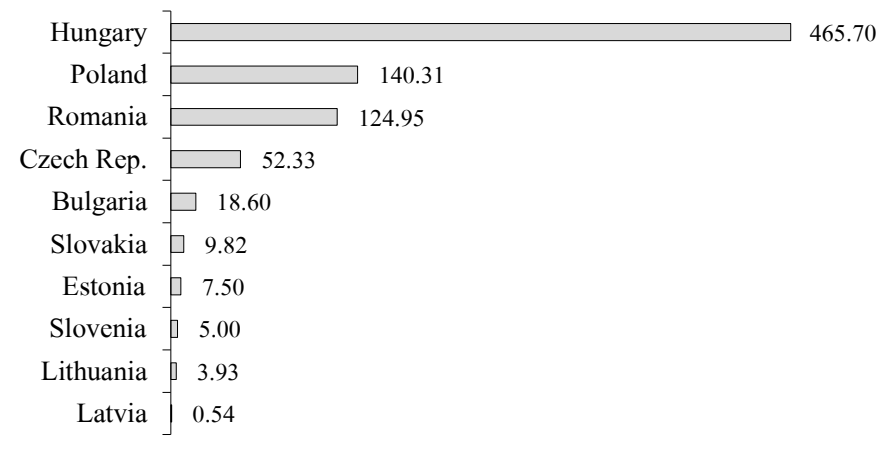

Fig. 1. China's outward FDI stock into Central and Eastern Europe countries (EU members) in 2010 (millions of USD)

Source: own research based on PRC's Ministry of Commerce (2010), p. 101.

The National Bank of Poland (NBP) reports Chinese FDI stock in Poland at $328 \mathrm{~m}$ USD (at the end of 2011). However, the 2006 report of Polish Information and Foreign Investment Agency (PAIIZ) accounted for only six Chinese investments in Poland ${ }^{23}$. Lodz hosts two factories - Yuncheng and Dong Yun - providing printing equipment, and Victory Technology factory, supplying parts for LCD TVs. TPV Displays, another supplier of electronic equipment, produces TV sets and LDC screens in two outlets in Lower Silesia region (Kobierzyce and Biskupice Podgórne. Min Hoong, a Chinese developer operating in Poland for 20 years, runs Zhong Hua hotel and restaurant in Sopot (Łazienki Południowe). Another developer, GD Poland Investments, operates a 40 ha Chinese Shopping Centre complex in Wólka Kosowska near Warsaw, an investment estimated at more than $150 \mathrm{~m}$ euro. Lastly, Chinese electronic companies ZTE and Huawei have invested in the IT sector.

Two Chinese companies are active on Polish automotive market. However, neither of them fits the category of foreign direct investment, since they involved acquisition of Polish factories from Delphi, a US automotive company. Late in 2009, Chinese company Beijing West Industries purchased a damper production factory in Krosno and parts of a research centre in Cracow from Delphi. Also in 2009, Chinese PCM company acquired the whole steering system department from Delphi, including two Polish outlets in Gliwice and Tychy. In 2009 alone, both factories produced 6 million steering systems, which constituted 50\% of global Delphi production in the sector. The largest Chinese direct investment in Poland is the Stalowa Wola steel mill, acquired by Chinese heavy machinery concern LiuGong. This is, notably, the first example of privatization in Poland financed entirely from Chinese capital. 
Further increase of Chinese FDI in Poland would require a central concept of Chinese economic involvement in our country, reflected in strategic documents and in training professional cadres for cooperation with Chinese partners. This aspect is largely overlooked by Polish authorities at present, as manifested by blatant inconsistencies, both in strategic documents ${ }^{24}$ and operational practice. This problem should be addressed soon, particularly in the light of Chinese declarations of cooperation and the spontaneous growth of Chinese migrant community in Poland.

At the end of 2010, according to NBP reports, total volume of Polish direct investment in China was 128 m USD, while 2010 Deloitte report estimates it at a higher level of ca. $150 \mathrm{~m}$ euro $^{25}$. However, as confirmed by both sources, Polish companies do not take advantage of own potential in this respect nor the cooperative potential offered by Chinese market. Polish investments in China are represented both by large corporations (KGHM, Kopex, Bioton, Amber Foods Polska and Polfa Łódź) and a number of small companies, predominantly of energy production, resources and pharmaceutical industries. An estimated 200 Polish companies operate on Chinese market at present.

Polish investors can profit from preferential tax levies on Chinese market. Those are limited, however, to selected sectors and projects, such as specialized technologies, environmental protection, agriculture, forestry, animal rearing, fishing, natural resources, infrastructure and green production. Tax concessions are also offered to venture capital projects. Potential benefits, preferences and tax levies aside, Polish entrepreneurs have to face numerous barriers and difficulties, both at the phase of establishing direct business contacts with Chinese partners, and in practical realization of investment projects.

\section{Conclusions}

China faces a great challenge of remodelling their path of economic development. Import and export of goods constitute $40 \%$ of Chinese gross domestic product, the largest trade partners being the EU, the US, Hong Kong, Japan and South Korea. The latent problem of mounting debt of both private and public companies remains, as well as growing social unrest and tension caused by limited social advancement and petrification of social strata can also pose a risk in the years to come. Irrespective of these problems, the Chinese will have to find new markets for their products and investments. Even if Chinese growth rate will lack the dynamics of the previous decade - and this is a very likely scenario - China will remain one of the largest potential investors on the Polish market. 
Chinese authorities are more and more aware of their country's role and significance in the global economy, and they have a well-defined strategy of economic involvement in Europe, with Poland regarded as one of the most promising areas of cooperation. This comes in stark contrast to the position of Polish government, largely unaware of the gravity of the situation. In this context, it is of utmost importance for our government to prepare a strategic document to address the Chinese perspective of investment in Poland, followed by a precise long-term strategy of cooperation with China.

The analysis of bilateral trade and investment relations between China and Poland presented herein shows the following regularities:

- In the 21st century, deficit of Poland's foreign trade with China increased more than nine times, reflecting the inability of Polish businesses to make good use of their export potential in relation with the Chinese market;

- The commodity structure of bilateral trade is not diversified, attesting to the inability of both Polish and Chinese businesses to utilize market potential of both economies, as well as insufficient understanding of demand structure of both markets;

- Studies of the structure of China's demand and export potential of Polish companies show that, in the decades to follow, there is a strong potential for growth and diversification of commodity structure in bilateral foreign trade relations;

- Foreign direct investment is one of the most important areas of potential development in bilateral relations. Investment relations between China and Poland are expected to develop, based on the announced strategy of Chinese central authorities towards the CEE countries, as well as growing significance of direct relations between regions and companies of both countries.

As shown in the structural analysis of goods trade between Poland and China, the present situation is not too optimistic. Moreover, the growing current account deficit, mostly of structural character, only adds to the problem. Consequently, decisive institutional measures should be taken, such as promotion of Polish products and services on the Chinese market, systemic methods for gathering information on perspectives and barriers to trade with China, and large-scale training and consulting services addressed to Polish companies already operating or planning to operate on the Chinese market. This two-way approach should result in increase of trade volume, development of the Polish export offer, and facilitated entry into the Chinese market. It should also create more investment opportunities for Polish companies interested in this direction of economic expansion. 


\section{Appendix 1}

Structure of Polish foreign trade with China in 2004 and 2011 (in \%), by SITC commodity specification standards (division)

\begin{tabular}{|c|c|c|c|c|}
\hline \multirow{2}{*}{ Specification by division } & \multicolumn{2}{|c|}{ Import } & \multicolumn{2}{|c|}{ Export } \\
\hline & 2004 & 2011 & 2004 & 2011 \\
\hline 1 & 2 & 3 & 4 & 5 \\
\hline Food and live animals & 2.39 & 2.18 & 0.90 & 1.87 \\
\hline Meat and meat preparations & 0.00 & 0.00 & 0.34 & 0.15 \\
\hline Live animals & 0.00 & 0.00 & 0.00 & 0.00 \\
\hline Dairy products and eggs & 0.00 & 0.00 & 0.32 & 1.29 \\
\hline Fish, crustaceans, molluscs and aquatic invertebrates, and preparations thereof & 1.31 & 1.23 & 0.02 & 0.01 \\
\hline Cereals and cereal preparations & 0.01 & 0.06 & 0.02 & 0.06 \\
\hline Vegetables and fruit & 0.55 & 0.64 & 0.14 & 0.14 \\
\hline Sugar and honey & 0.05 & 0.08 & 0.00 & 0.08 \\
\hline Coffee, tea, cocoa, spices & 0.33 & 0.10 & 0.07 & 0.06 \\
\hline Feeding stuff for animals & 0.10 & 0.02 & 0.00 & 0.01 \\
\hline Miscellaneous edible products and preparations & 0.00 & 0.06 & 0.00 & 0.09 \\
\hline Beverages and tobacco & 0.02 & 0.20 & 0.02 & 0.01 \\
\hline Beverages & 0.00 & 0.00 & 0.02 & 0.01 \\
\hline Tobacco and tobacco manufactures & 0.02 & 0.20 & 0.00 & 0.00 \\
\hline Crude materials inedible, except fuels & 3.71 & 1.27 & 2.67 & 4.87 \\
\hline Hides, skins and furskins, raw & 0.00 & 0.00 & 0.02 & 0.17 \\
\hline Oil-seeds and oleaginous fruits & 0.47 & 0.06 & 0.00 & 0.01 \\
\hline Crude rubber & 0.02 & 0.04 & 0.03 & 0.92 \\
\hline Cork and wood & 0.01 & 0.05 & 0.07 & 0.09 \\
\hline Pulp and waste paper & 0.00 & 0.00 & 0.00 & 0.01 \\
\hline Textile fibres and their wastes & 0.04 & 0.08 & 0.02 & 0.01 \\
\hline Crude fertilizers and crude minerals & 0.21 & 0.28 & 0.02 & 0.01 \\
\hline Metalliferous ores and metal scrap & 0.11 & 0.11 & 1.95 & 2.43 \\
\hline Crude animal and vegetable materials, n.e.s. & 2.86 & 0.65 & 0.56 & 1.21 \\
\hline Mineral fuels, lubricants and related materials & 0.06 & 0.18 & 0.01 & 0.52 \\
\hline Coal, coke and briquettes & 0.02 & 0.00 & 0.00 & 0.00 \\
\hline Petroleum, petroleum products and related materials & 0.04 & 0.18 & 0.01 & 0.52 \\
\hline Gas natural and manufactured & 0.00 & 0.00 & 0.00 & 0.00 \\
\hline Electric current & 0.00 & 0.00 & 0.00 & 0.00 \\
\hline Animal and vegetable oils, fats and waxes & 0.00 & 0.01 & 0.00 & 0.00 \\
\hline Animal oils and fats & 0.00 & 0.01 & 0.00 & 0.00 \\
\hline Fixed vegetable fats and oils, crude, refined or fractionated & 0.00 & 0.00 & 0.00 & 0.00 \\
\hline Animal or vegetable fats and oils, processed, n.e.s. & 0.00 & 0.00 & 0.00 & 0.00 \\
\hline Chemicals and related products & 4.12 & 4.45 & 21.68 & 13.65 \\
\hline Organic chemicals & 1.30 & 1.14 & 19.98 & 10.58 \\
\hline Inorganic chemicals & 0.77 & 0.61 & 0.36 & 0.38 \\
\hline Dyeing, tanning and colouring materials & 0.13 & 0.14 & 0.01 & 0.08 \\
\hline Medicinal and pharmaceutical products & 0.41 & 0.49 & 0.02 & 0.22 \\
\hline Essential oils and resinoids and perfume materials, toilet preparations & 0.05 & 0.53 & 0.13 & 0.07 \\
\hline
\end{tabular}




\begin{tabular}{|c|c|c|c|c|}
\hline 1 & 2 & 3 & 4 & 5 \\
\hline Fertilizers (other than those of group 272) & 0.02 & 0.00 & 0.00 & 0.02 \\
\hline Plastics in primary forms & 0.32 & 0.21 & 0.75 & 0.96 \\
\hline Plastics in non-primary forms & 0.49 & 0.74 & 0.27 & 0.43 \\
\hline Chemical materials and products, n.e.s. & 0.62 & 0.59 & 0.02 & 0.91 \\
\hline Manufactured goods classified chiefly by material & 16.49 & 16.39 & 33.98 & 49.61 \\
\hline Leather, leather manufactures n.e.s., and dressed furskins & 0.04 & 0.02 & 0.00 & 0.08 \\
\hline Rubber manufactures, n.e.s. & 0.39 & 0.85 & 0.40 & 1.70 \\
\hline Cork and wood manufactures (excluding furniture) & 0.31 & 0.50 & 0.13 & 0.14 \\
\hline Paper, paperboard and articles thereof & 0.32 & 0.46 & 2.66 & 0.33 \\
\hline Textile yarn, fabrics, made-up articles, n.e.s. & 5.39 & 3.01 & 0.17 & 0.34 \\
\hline Non-metallic mineral manufactures, n.e.s. & 2.47 & 2.58 & 0.91 & 1.14 \\
\hline Iron and steel & 0.86 & 2.20 & 6.46 & 0.74 \\
\hline Non-ferrous metals & 0.36 & 0.85 & 22.45 & 43.19 \\
\hline Manufactures of metals, n.e.s & 6.35 & 5.92 & 0.78 & 1.95 \\
\hline Machinery and transport equipment & 42.50 & 52.36 & 37.85 & 21.20 \\
\hline Power-generating machinery and equipment & 0.37 & 1.58 & 4.84 & 2.16 \\
\hline Machinery specialized for particular industries & 0.88 & 1.46 & 0.66 & 1.91 \\
\hline Metalworking machinery & 0.22 & 0.42 & 0.46 & 0.27 \\
\hline General industrial machinery and equipment and machine parts, n.e.s. & 4.06 & 5.90 & 2.60 & 3.44 \\
\hline Office machines and automatic data processing machines & 11.57 & 14.13 & 0.10 & 1.29 \\
\hline Telecommunications and sound recording and reproducing apparatus and equipment & 7.84 & 11.76 & 2.50 & 1.92 \\
\hline Electrical machinery, apparatus and appliances & 11.68 & 14.46 & 3.32 & 7.86 \\
\hline Road vehicles (including air-cushion vehicles) & 2.97 & 2.52 & 0.80 & 1.82 \\
\hline Other transport equipment & 2.91 & 0.14 & 22.58 & 0.53 \\
\hline Miscellaneous manufactured articles & 30.71 & 22.88 & 2.89 & 8.26 \\
\hline Prefabricated buildings; sanitary, plumbing, heating and lighting fixtures and fittings, n.e.s. & 1.74 & 1.92 & 0.25 & 1.19 \\
\hline Furniture and parts thereof & 1.34 & 2.29 & 0.67 & 4.29 \\
\hline Travel goods, handbags and similar containers & 1.58 & 1.00 & 0.00 & 0.00 \\
\hline Articles of apparel and clothing accessories & 10.18 & 6.82 & 0.01 & 0.04 \\
\hline Footwear & 3.33 & 1.80 & 0.01 & 0.00 \\
\hline Professional, scientific and controlling instruments and apparatus, n.e.s. & 0.90 & 1.68 & 0.35 & 1.29 \\
\hline Photographic apparatus, equipment and supplies and optical goods, n.e.s.; watches and clocks & 0.97 & 0.68 & 0.38 & 0.07 \\
\hline Miscellaneous manufactured articles, n.e.s. & 10.67 & 6.69 & 1.24 & 1.38 \\
\hline Commodities and transactions not classified elsewhere in SITC & 0.00 & 0.01 & 0.00 & 0.00 \\
\hline Total & 100.00 & 100.00 & 100.00 & 100.00 \\
\hline
\end{tabular}

Source: own research based on data from Eurostat, European Commission, http://epp.eurostat.ec.europa.eu. 


\section{Notes}

1 Zhu, Kotz (2010).

${ }^{2}$ Chow, Li (2002), pp. 247-248.

${ }^{3}$ Zhu, Kotz (2008), pp. 18-21.

${ }^{4}$ Borst (2012); Wong (2012).

${ }^{5}$ Starzyk (2009), p. 29.

${ }^{6}$ Reuters (2012).

7 Atsmon et al. (2012), p. 10.

${ }^{8}$ In the next decade, China is expected to maintain its 2010 status of second largest global economy, after United States and before Japan, doubling its share in global product from 9 to $19 \%$.

${ }^{9} \mathrm{G} 3$ is considered as the grouping including: Japan and the European Union (Austria, Belgium, Bulgaria, Croatia (since 2013), Cyprus, Czech Republic, Denmark, Estonia, Finland, France, Germany, Greece, Hungary, Ireland, Italy, Latvia, Lithuania, Luxembourg, Malta, Netherlands, Poland, Portugal, Romania, Slovakia, Slovenia, Spain, Sweden, United Kingdom) and the United States.

${ }^{10}$ In the light of the World Bank reports, the increase of money supply M2, annually, has reached $28.4 \%$, at an average annual growth rate of less than $18 \%$ in the first decade of the 21 st century.

${ }^{11}$ This index reflects the maximum level of governmental obligations in the case of low profitability of investment projects financed from public debt.

${ }^{12}$ McKinsey \& Company report attributes economic growth in the period 2000-2010 to investment; the share of individual consumption in GDP increase over the same period has dropped from $46 \%$ to $33 \%$.

${ }^{13}$ It is estimated that, by 2020 , the first generation of migrants from rural areas will constitute nearly $20 \%$ of Chinese urban population. At present, urban population of China is estimated at $650 \mathrm{~m}$, and is expected to rise to $850 \mathrm{~m}$ within the next decade.

14 Arnold et al. (2011), p. 10.

${ }^{15}$ It must be noted that the overwhelming majority of local businesses finance their development programs out of their own resources.

${ }^{16}$ Segmentation adopting the category of urban clusters serves to isolate new markets, taking into consideration not only geographic location, but also such attributes of the region as income, local dialect, economic and trade relations, as well as customer preferences and purchasing behaviours.

${ }^{17}$ Main topics of PM Wen Jiabao's speech presented at the International Economic Forum "Poland-Central EuropeChina" in Warsaw, April 262012.

18 Based on 2011 average yuan exchange rate, this corresponds to ca. 310 thousand USD.

${ }^{19}$ Clegg, Voss (2012), p. 11.

${ }^{20}$ Own calculations based on Table 4 data

${ }^{21}$ China Greentech Initiative (2011).

22 Based on: Drelich-Skulska et al. (2012).

${ }^{23}$ Chińskie inwestycje w Polsce (2011).

${ }^{24}$ Such inconsistencies can be observed, for example, by comparing March 2012 document published by Polish Ministry of Foreign Affairs (Priorytety polskiej polityki zagranicznej 2012-2016) against the declarations contained in the agreement between Poland and People's Republic of China concerning strategic partnership alliance.

${ }^{25}$ Delloitte: niewielkie inwestycje... (2012). 


\section{References}

Arnold, K.M., Breul, R., Lou, J., Mylavarapu, S., von Roda, A.G., Sibal, D.R., Xu, T. \& Yang, X. (2011). Facing the Challenges. Three Scenarios for Global Economic Governance in 2020. Global Governance 2020 Project Team. Berlin: Global Public Policy Institute.

Atsmon, Y., Magni, M., Li, L. \& Liao, W. (2012). Meet the 2020 Chinese Consumer. McKinsey Consumer \& Shopper Insights.

Borst, N. (2012). The Chinese Growth Model: Before and After the Crisis, www.piie.com/blogs/ china/?p=1401.

China Greentech Initiative (2011). The China Greentech Report 2011. China's Emergence as a Global Greentech Market Leader, www.pwc.dk/da_DK/dk/nyt/csr/assets/china-greentech-report.pdf.

Chińskie inwestycje w Polsce (2011), http://wyborcza.biz/biznes/1,101562,9812911,Chinskie inwestycje_w_Polsce.html.

Chow, G.C. \& Li, K.-W. (2002). China's Economic Growth: 1952-2010. Economic Development and Cultural Change, 15 (1). Chicago: The University of Chicago Press.

Clegg, J. \& Voss, H. (2012). Chinese Overseas Direct Investment in the European Union. London: ECRAN.

Delloitte: niewielkie inwestycje polskich firm $w$ Chinach (2012), http://wyborcza.biz/bizn es/1,100969,12551330,Deloitte_niewielkie_inwestycje_polskich_firm_w_Chinach. html\#ixzz2JAh36DnI.

Drelich-Skulska, B., Bobowski, S., Jankowiak, A.H. \& Skulski, P. (2012). Nisze rynkowe dla polskich produktów w Chinach. An expert opinion commissioned by Polish Information and Foreign Investment Agency.

Eurostat, European Commission, http://epp.eurostat.ec.europa.eu.

Jiabao, W. (2012). Poland - Central Europe - China. Warsaw: International Economic Forum.

Ministerstwo Spraw Zagranicznych RP (2012). Priorytety polskiej polityki zagranicznej 2012 2016, www.msz.gov.pl/pl/polityka_zagraniczna/priorytety_polityki_zagr_2012_2016.

PRC's Ministry of Commerce (2010). Statistical Bulletin of China's Outward Foreign Direct Investment. Beijing.

Reuters (2012). World Bank cuts East Asia GDP outlook, flag China risks, www.reuters.com/ article/2012/10/08/us-worldbank-asia-outlook-idUSBRE89701420121008.

Rocznik Statystyczny Handlu Zagranicznego. (2004, 2005, 2006, 2007, 2008, 2009, 2010, 2011, 2012). Warszawa: Central Statistical Office.

Starzyk, K. (2009). Zagraniczna polityka ekonomiczna w procesie rynkowej transformacji gospodarki. Przypadek Chin. Warszawa: Wydawnictwo PLACET. 
The National Bureau of Statistics of China (2008). China Statistical Yearbook 2008, Beijing. The National Bureau of Statistics of China (2009). China Statistical Abstract. Beijing.

U.S. \& Foreign Commercial Service and U.S. Department Of State (2012). Doing Business in China, 2012 Country Commercial Guide for U.S. Companies.

U.S. Department of Commerce (2011). China Business Handbook, U.S. Commercial Services and Asia Briefing Ltd.

Woetzel, J., Mendonca, L., Devan, J., Negri, S., Hu, Y., Jordan, L., Li, X., Maasry, A., Tsen, G. \& Yu, F. (2009). Preparing for China's Urban Billion. McKinsey Global Institute.

Wong, E. (2012). China's Growth Slows, and Its Political Model Shows Limits. New York Times 11 May 2012, www.nytimes.com/2012/05/11/world/asia/chinas-unique-economic-modelgets-new-scrutiny.html?pagewanted=all\&_r=1\&.

www.china-ship.com/en/news.php?id=122.

Zhu, A. \& Kotz, D.M. (2008). China's Growth Model: Problems and Alternatives, www.networkideas.org/ideasact/jan09/pdf/andong.pdf.

Zhu, A. \& Kotz, D.M. (2010). The Dependence of China's Economic Growth on Exports and Investment, http://people.umass.edu/dmkotz/China_Growth_Model_\%2010_09.pdf. 